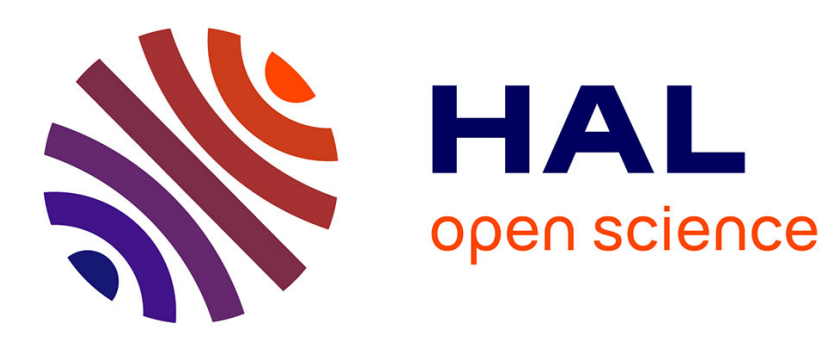

\title{
An expeditious method for the selective cyclotrimerization of isocyanates initiated by TDAE
} Alain G Giuglio-Tonolo, Cédric Spitz, Thierry Terme, Patrice Vanelle

\section{To cite this version:}

Alain G Giuglio-Tonolo, Cédric Spitz, Thierry Terme, Patrice Vanelle. An expeditious method for the selective cyclotrimerization of isocyanates initiated by TDAE. Tetrahedron Letters, 2014, 55 (16), pp.2700 - 2702. 10.1016/j.tetlet.2014.03.045 . hal-01425614

\section{HAL Id: hal-01425614 https://hal-amu.archives-ouvertes.fr/hal-01425614}

Submitted on 12 Jan 2017

HAL is a multi-disciplinary open access archive for the deposit and dissemination of scientific research documents, whether they are published or not. The documents may come from teaching and research institutions in France or abroad, or from public or private research centers.
L'archive ouverte pluridisciplinaire HAL, est destinée au dépôt et à la diffusion de documents scientifiques de niveau recherche, publiés ou non, émanant des établissements d'enseignement et de recherche français ou étrangers, des laboratoires publics ou privés. 


\section{Graphical Abstract}

To create your abstract, type over the instructions in the template box below.

Fonts or abstract dimensions should not be changed or altered.

An expeditious method for the selective cyclotrimerization of isocyanates initiated by

TDAE

Alain G. Giuglio-Tonolo, Cédric Spitz, Thierry Terme, Patrice Vanelle

$$
\text { R-NCO } \frac{(2 \mathrm{~mol} \%)}{\text { r.t., } 10 \text { s to } 15 \mathrm{~min}}
$$


Tetrahedron Letters

journal homepage: www.elsevier.com

\title{
An expeditious method for the selective cyclotrimerization of isocyanates initiated by TDAE
}

\author{
Alain G. Giuglio-Tonolo, Cédric Spitz, Thierry Terme, Patrice Vanelle* \\ Aix-Marseille Université, Institut de Chimie Radicalaire (ICR)- UMR CNRS 7273-Equipe de Pharmacochimie Radicalaire (LPCR), Faculté de Pharmacie, 27 \\ Bd Jean Moulin, 13385 Marseille-CS30064-cedex 05, France.
}

\section{ARTICLE INFO}

\section{ABSTRACT}

\section{Article history:}

Received

Received in revised form

Accepted

Available online

\section{Keywords:}

Isocyanates

Cyclotrimerization

TDAE

Solvent-free

Isocyanurates
We developed a rapid and green synthesis of various isocyanurates by cyclotrimerization of isocyanates using TDAE (tetrakis(dimethylamino)ethylene). TDAE displays excellent performance in catalytic quantities, affording the corresponding trimer of isocyanates very rapidly, under air and at room temperature with good to excellent yields.
1,3,5-Triazinane-2,4,6-triones or isocyanurates, with their high thermal stability, are used to enhance the physical properties of polyurethanes and coating materials. ${ }^{1}$ Incorporation of isocyanurates into the framework of polyurethanes increases thermal and chemical resistance, flame retardation, as well as film-forming characteristics. ${ }^{2}$ Isocyanurates are also employed in other areas such as chiral discrimination, ${ }^{3}$ selective ion bonding ${ }^{4}$ and drug delivery. ${ }^{5}$ Triaryl isocyanurates are often used as activators for the polymerization and postpolymerization of $\varepsilon$ caprolactam in the production of nylons with high melt viscosities. $^{6}$

The general route for the preparation of isocyanurates is the cyclotrimerization of the corresponding isocyanates. A number of reports have been published concerning this method using a variety of different Lewis-basic catalysts, including phosphines, ${ }^{7}$ amines, ${ }^{8} \quad \mathrm{NO},{ }^{9}$ alkoxyallenes, ${ }^{10}$ fluoride anions, ${ }^{11} p$ toluenesulfinates, ${ }^{12}$ carbamate anions, ${ }^{13}$ cyanates, ${ }^{14}$ and $N$ heterocyclic carbenes. ${ }^{15}$ Organometallic catalysts such as lithium amides, ${ }^{16}$ alkylzinc amines and alkoxides, ${ }^{17}$ tin complexes, ${ }^{18}$ palladium(0), ${ }^{19}$ copper(II) and nickel(II) halides ${ }^{9}$ also allowed the cyclotrimerization of isocyanates. But, many of the known cyclotrimerization procedures suffer from low catalyst activity, diazetidine byproduct formation, lengthy reaction times, product separation difficulties and the use of toxic solvents. ${ }^{15,20}$

Therefore, developing catalysts which promote cyclotrimerization selectively is of great importance due to wide application of isocyanurate structure in both industry and academic studies. ${ }^{1-6}$
Tetrakis(dimethylamino)ethylene ${ }^{21}$ (Figure 1) is an electronrich organic reductant, which reacts with halogenated derivatives to generate an anion under mild conditions via two sequential single electron transfers.<smiles>CN(C)C(=C(N(C)C)N(C)C)N(C)C</smiles>

Figure 1. Structure of TDAE

During our investigation of 9-bromofluorene addition to phenyl isocyanate in the presence of TDAE, we discovered that TDAE allowed the cyclotrimerization of isocyanates to their respective isocyanurates. Herein, we report further details about this efficient and straightforward isocyanurates synthesis using commercially available TDAE.

Phenyl isocyanate 1a was used as model substrate for the optimization of the cyclotrimerization conditions and the results are summarized in Table 1. We first carried out a reaction using an equimolar amount of TDAE and phenyl isocyanate in anhydrous THF at room temperature. The conversion, monitored by TLC, was complete after $15 \mathrm{~min}$. A complex mixture was obtained and triphenylisocyanurate $\mathbf{2 a}$ was isolated in only $25 \%$ yield (Entry 1). Using $40 \mathrm{~mol} \%$ of TDAE resulted in a small decrease of the by-products proportions and allowed 2a in $35 \%$ yield (Entry 2). With $15 \mathrm{~mol} \%$ of TDAE, a dramatic improvement was observed and 2a was isolated in 69\% yield (Entry 3). A variety of solvents were screened (Entries 4-7) and ethyl acetate gave the best result ( $71 \%$ yield, Entry 7$)$.

* Corresponding author. Tel.: +0-000-000-0000; fax: +0-000-000-0000; e-mail: author@university.edu 
Performing the reaction under air gave a similar yield than under nitrogen (Entry 7 vs 8).

Table 1. Optimization of the cyclotrimerization of phenyl isocyanate initiated by TDAE

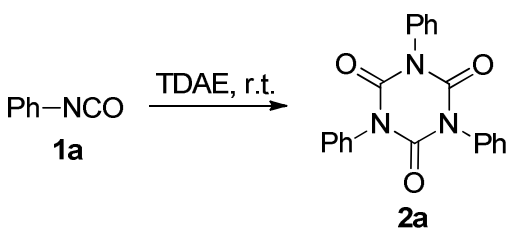

\begin{tabular}{ccccc}
\hline Entry & $\begin{array}{c}\text { TDAE } \\
(\mathrm{mol} \%)\end{array}$ & Solvent & Time & \% Yield $2 \mathbf{a}$ \\
\hline 1 & 100 & THF & $15 \mathrm{~min}$ & $25^{\mathrm{b}}$ \\
2 & 40 & THF & $15 \mathrm{~min}$ & $35^{\mathrm{b}}$ \\
3 & 15 & THF & $15 \mathrm{~min}$ & $69^{\mathrm{b}}$ \\
4 & 15 & Cyclohexane & $15 \mathrm{~min}$ & $63^{\mathrm{b}}$ \\
5 & 15 & $n$-Heptane & $15 \mathrm{~min}$ & $70^{\mathrm{b}}$ \\
6 & 15 & Diethyl ether & $15 \mathrm{~min}$ & $46^{\mathrm{b}}$ \\
7 & 15 & Ethyl acetate & $15 \mathrm{~min}$ & $71^{\mathrm{b}}$ \\
8 & 15 & Ethyl acetate & $15 \mathrm{~min}$ & $69^{\mathrm{c}}$ \\
9 & 15 & None & $10 \mathrm{~s}$ & $67^{\mathrm{c}}$ \\
10 & 5 & None & $10 \mathrm{~s}$ & $80^{\mathrm{c}}$ \\
11 & 2 & None & $10 \mathrm{~s}$ & $81^{\mathrm{c}}$ \\
12 & 2 & Ethyl acetate & $15 \mathrm{~min}$ & $70^{\mathrm{c}, \mathrm{d}}$ \\
13 & None & None & $12 \mathrm{~h}$ & $16^{\mathrm{c}}$ \\
\hline
\end{tabular}

${ }^{a}$ Isolated yields. ${ }^{b}$ Reactions were performed under nitrogen at room temperature using $2 \mathrm{~mL}$ of anhydrous non-degassed solvent. ${ }^{\mathrm{c}}$ Reactions were performed under air at room temperature. ${ }^{\mathrm{d}}$ Reaction was performed with 0.5 $\mathrm{mL}$ of ethyl acetate.

Then, we explored the possibility to run the reaction without solvent under air with 15 mol\% of TDAE. After 10 seconds, the mixture became completely solid, so the reaction was stopped. Interestingly, the trimer 2a was isolated with a yield similar to those obtained with ethyl acetate as solvent (Entry 8 vs 9). This encouraging finding prompted us to investigate the influence of TDAE amount in solvent-free conditions under air. Decreasing the amount of TDAE from $15 \mathrm{~mol} \%$ to $5 \mathrm{~mol} \%$ resulted in a slightly improvement (80\% yield, Entry 10). No significant effect was observed between $5 \mathrm{~mol} \%$ and $2 \mathrm{~mol} \%$ of TDAE (Entry 10 $v s$ 11). Using a small amount of ethyl acetate as solvent resulted in a slightly lower yield of trimer 2a (Entry 12). A control experiment without catalyst (Entry 13) showed the importance of TDAE to achieve good yields.

So, the method developed here is very simple, fast and environmentally-friendly as it allowed the formation of the trimer under air at room temperature in only 10 seconds without solvent. Furthermore, separation of the desired product was achieved by simply triturating and filtering the crushed reaction mixture with cold diethyl ether and water, successively.

With the optimized conditions in hand, we proceeded to investigate the substrate scope of the reaction. The results are shown in Table 2. Under the optimized solvent-free reaction conditions, a variety of liquid isocyanates were converted to the corresponding isocyanurates in very good yields (Entry 1-7). Both electron-donating and electron-withdrawing substituents on the aryl group are well tolerated. Interestingly, a benzyl substituent gave also a very good $93 \%$ yield of the corresponding isocyanurate $\mathbf{2 g}$ (Entry 7).

The reactivity of solid isocyanates was then studied with the optimized conditions. But, our preliminary attempt with nitrophenyl isocyanate, previously powdered in a mortar with a pestle, and $2 \mathrm{~mol} \%$ of TDAE at room temperature, did not allow the formation of the corresponding isocyanurate $\mathbf{2 h}$. So, we further investigated the use of a minimum amount of solvent. When 2 mol\% of TDAE was added to a solution of nitrophenyl isocyanate in $0.5 \mathrm{~mL}$ of ethyl acetate under air, the corresponding trimer $\mathbf{2 h}$ was isolated in $81 \%$ yield (Entry 8). With these new conditions for solid isocyanates in hand, the scope of the cyclotrimerization using a variety of solid isocyanates was explored and gave good to excellent yields of the corresponding isocyanurates 2i-k (Entry 9-11).

Table 2. Scope of the cyclotrimerization of various isocyanates.

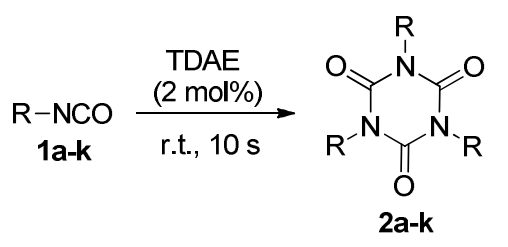

\begin{tabular}{|c|c|c|c|}
\hline Entry & $\mathrm{RNCO}$ & Solvent & $\%$ Yield $^{\mathrm{a}, \mathrm{b}} \mathbf{2 a - k}$ \\
\hline 1 & & none & $81 \mathbf{2 a}$ \\
\hline 2 & & none & $95 \mathbf{2 b}$ \\
\hline 3 & & none & $92 \mathbf{2 c}$ \\
\hline 4 & & none & 94 2d \\
\hline 5 & & none & $91 \mathbf{2 e}$ \\
\hline 6 & & none & $91 \mathbf{2 f}$ \\
\hline 7 & & none & $932 \mathrm{~g}$ \\
\hline 8 & & EtOAc & $81^{\mathrm{c}} \mathbf{2 h}$ \\
\hline 9 & & EtOAc & $76^{\mathrm{c}} 2 \mathrm{i}$ \\
\hline 10 & & EtOAc & $90^{\mathrm{c}} \mathbf{2} \mathbf{j}$ \\
\hline 11 & & EtOAc & $82^{\mathrm{c}} \mathbf{2 k}$ \\
\hline
\end{tabular}

${ }^{\mathrm{a}}$ Isolated yields. ${ }^{\mathrm{b}}$ Reactions were performed under air at room temperature. ${ }^{\mathrm{c}} 0.5 \mathrm{~mL}$ of EtOAc was used and the reaction was stirred for $15 \mathrm{~min}$.

Based on the ability of TDAE to give electrons and on a recent paper showing that the trimerization of isocyanates can be initiated by an electron, ${ }^{22}$ we propose a similar mechanism involving an anion radical intermediate formed by donation of an electron of TDAE to the isocyanate.

In conclusion, commercially available TDAE has been used for the first time to catalyze the cyclotrimerization of a wide range of aryl isocyanates and benzyl isocyanate to isocyanurates in high yield. The important features of our method are: solventfree conditions with liquid isocyanates, mild reaction conditions under air, very short time reaction and simple purification procedure. 


\section{Acknowledgments}

This work was supported by the Centre National de la Recherche Scientifique and the Aix-Marseille Université. The authors thank V. Remusat for ${ }^{1} \mathrm{H}$ and ${ }^{13} \mathrm{C}$ spectra recording and $\mathrm{T}$. Schembri for mass spectra recording.

\section{References and notes}

1. Lin, I. S.; Kresta, J. E.; Frisch, K. C. Reaction Injection Molding and Fast Polymerization Reactions, Plenum Publishing, New York, 1982, p. 147.

2. (a) Nicholas, L.; Gmitter, G. R. J. Cell. Plast. 1965, 85. (b) Nawata, T.; Kresta, J. E.; Frisch, K. C. J. Cell. Plast. 1975, 267. (c) Zitinkina, A. K.; Sibanova, N. A.; Tarakanov, O. G. Russ. Chem. Rev. 1985, 54, 1866. (d) Wirpsza, Z. Polyurethanes: Chemistry, Technology and Application; Ellis Horwood: London, UK, 1993.

3. Sugimoto, H.; Yamane, Y.; Inoue, S. Tetrahedron: Asymmetry 2000, 11, 2067.

4. Mascal, M.; Yakovlev, I.; Nikitin, E. B.; Fettinger, J. C. Angew. Chem. Int. Ed. 2007, 46, 8782.

5. Murray, A. P.; Miller, M. J. J. Org. Chem. 2003, 68, 191.

6. (a) Horsky, J.; Kubanek, V.; Marick, J.; Kralicek, J. Chem. Prum. 1982, 32, 599. (b) Bukac, Z.; Sebenda, J. Chem. Prum. 1985, 35, 361.

7. Tang, J.; Mohan, T.; Verkade, J. G. J. Org. Chem. 1994, 59, 4931.

8. (a) Kogon, I. C. J. Am. Chem. Soc. 1956, 78, 4911. (b) Richter, R.; Ulrich, H. Synthesis 1975, 463. (c) Wong, S.; Frisch, K. C. J. Polym. Sci. Polym. Chem. Ed. 1986, 24, 2877. (d) Taguchi, Y.; Shibuya, I.; Yasumoto, Y.; Tsuchiya, T.; Yonemoto, K. Bull. Chem. Soc. Jpn. 1990, 63, 3486.

9. Villa, J. F.; Powell, H. B. Synth. React. Inorg. Met.-Org. Chem. 1976, 6, 59.

10. Mizuya, J.; Yokozawa, T.; Endo, T. J. Polym. Sci., Polym. Chem 1991, 29, 1545

11. Nambu, Y.; Endo, T. J. Org. Chem. 1993, 58, 1932.

12. Moghaddam, F. M.; Dekamin, M. G.; Khajavi, M. S.; Jalili, S. Bull. Chem. Soc. Jpn. 2002, 75, 851.

13. Khajavi, M. S.; Dakamin, M.; Hazarkhani, H. J. Chem. Research. 2000, 145.

14. Tanimoto, F.; Tanka, T.; Kitano, H.; Fukui, K. Bull. Chem. Soc. Jpn. 1966, 39, 1922.

15. Duong, H. A.; Cross, M. J.; Louie, J. Org. Lett. 2004, 6, 4679.

16. Shi, J.; Guo, Z.; Wei, X.; Liu, D.; Lappert, M. F. Synlett 2011, 1937.

17. Noltes, J. G.; Boersma, J. J. Organomet. Chem. 1967, 7, 6.

18. Foley, S. R.; Yap, G. P. A.; Richeson, D. S. Organometallics 1999, 18,4700 .

19. Paul, F.; Moulin, S.; Piechaczyk, O.; Le Floch, P.; Osborn, J. A. J. Am. Chem. Soc. 2007, 129, 7294.

20. (a) Wegener, G.; Brandt, M.; Duda, L.; Hofmann, J.; Klesczewski, B.; Koch, D.; Kumpf, R.-J.; Orzesek, H.; Pirkl, H.-G.; Six, C.; Steinlein, C.; Weisbeck, M. Appl. Catal. A 2001, 221, 303. (b) Silva, A. L.; Bordado, J. C. Catal. Rev. 2004, 46, 31.

21. (a) Giuglio-Tonolo, G.; Terme, T.; Medebielle, M.; Vanelle, P. Tetrahedron Lett. 2003, 44, 6433. (b) Giuglio-Tonolo, G.; Terme, T.; Medebielle, M.; Vanelle, P. Tetrahedron Lett. 2004, 45, 512. (c) Giuglio-Tonolo, G.; Terme, T.; Vanelle, P. Synlett 2005, 251. (d) Amiri-Attou, O.; Terme, T.; Vanelle, P. Molecules 2005, 10, 545. (e) Montana, M.; Terme, T.; Vanelle, P. Tetrahedron Lett. 2006, 47, 6573. (f) Spitz, C.; Khoumeri, O.; Terme, T.; Vanelle, P. Synlett 2013, 1725. (g) Khoumeri, O.; Spitz, C.; Terme, T.; Vanelle, P. Molecules 2013, 18, 7364. (h) Primas, N.; Neildé, K.; Kabri, Y.; Crozet, M. D.; Terme, T.; Vanelle, P. Synthesis 2014, 46, 348.

22. (a) Peters, S. J.; Klen, J. R.; Smart, N. C. Org. Lett. 2008, 10, 4521. (b) Servos, M. A.; Smart, N. C.; Kassabaum, M. E.; Scholtens, C. A.; Peters, S. J. J. Org. Chem. 2013, 78, 3908.

23. General procedure for liquid isocyanates $\mathbf{2 a - g}$ : TDAE $(9.3 \mu \mathrm{L}$; $0.04 \mathrm{mmol} ; 2 \mathrm{~mol} \%$ ) was added to a vial containing the isocyanate ( $2 \mathrm{mmol}$ ) under air at room temperature with vigorous stirring. The mixture became completely solid after 10 seconds. The crude mixture was then crushed and $6 \mathrm{~mL}$ of cold diethyl ether was added followed by 1 minute stirring. After filtering and washing with additional diethyl ether and water, successively, the desired isocyanurate was isolated by simple filtration without further purification.

General procedure for solid isocyanates $\mathbf{2 h}-\mathbf{k}$ : To a solution of isocyanate $(2 \mathrm{mmol})$ in EtOAc $(0.5 \mathrm{~mL})$ was added TDAE $(9.3 \mu \mathrm{L}$;
$0.04 \mathrm{mmol} ; 2 \mathrm{~mol} \%$ ) under air at room temperature with vigorous stirring. After 15 minutes, the solvent was evaporated under reduced pressure. The resulting mixture was then crushed and $2 \mathrm{~mL}$ of cold diethyl ether was added followed by 1 minute stirring. After filtering and washing with additional diethyl ether and water, the desired isocyanurate was isolated by simple filtration without further purification.

Analyses for compounds $\mathbf{2 a}, \mathbf{2 b}, \mathbf{2 c}, \mathbf{2 e}, \mathbf{2 f}, \mathbf{2 g}, \mathbf{2 h}, \mathbf{2 i}$ and $\mathbf{2 j}$ are in agreement with those reported in the literature. ${ }^{16,24,25,26}$

1,3,5-tris-(3-methoxyphenyl)-1,3,5-triazinane-2,4,6-trione $\mathbf{2 d :} \mathrm{mp}$ $210{ }^{\circ} \mathrm{C} ;{ }^{1} \mathrm{H}$ NMR $\left(200 \mathrm{MHz}, \mathrm{CDCl}_{3}\right): \delta=7.44-7.35(\mathrm{~m}, 3 \mathrm{H}), 7.02-$ $6.92(\mathrm{~m}, 9 \mathrm{H}), 3.82(\mathrm{~s}, 9 \mathrm{H}) ;{ }^{13} \mathrm{C} \mathrm{NMR}\left(50 \mathrm{MHz}, \mathrm{CDCl}_{3}\right): 160.3$, 148.4, 134.4, 129.9, 120.5, 115.4, 114.1, 55.4.

1,3,5-tris(3,5-dichlorophenyl)-1,3,5-triazinane-2,4,6-trione $\mathbf{2 k}$ : mp $179{ }^{\circ} \mathrm{C} ;{ }^{1} \mathrm{H} \mathrm{NMR}\left(200 \mathrm{MHz}, \mathrm{CDCl}_{3}\right): \delta=7.51-7.49(\mathrm{t}, J=1.8 \mathrm{~Hz}$, $3 \mathrm{H}), 7.31(\mathrm{~d}, J=1.8 \mathrm{~Hz}, 6 \mathrm{H}) ;{ }^{13} \mathrm{C}$ NMR $\left(50 \mathrm{MHz}, \mathrm{CDCl}_{3}\right): 147.2$, 135.8, 134.3, 130.3, 127.4.

24. Wang, H.-M.; Li, H.-X.; Yu, X.-Y.; Ren, Z.-G.; Lang, J.-P. Tetrahedron 2011, 67, 1530.

25. Li, Y.; Matsumura, H.; Yamanaka, M.; Takahashi, T. Tetrahedron 2004, 60, 1393.

26. Argouarch, G.; Veillard, R.; Roisnel, T.; Amar, A.; Meghezzi, H.; Boucekkine, A.; Hugues, V.; Mongin, O.; Blanchard-Desce, M.; Paul, F. Chem. Eur. J. 2012, 18, 11811. 